\title{
A ética da reciprocidade: diálogo com Martin Buber
}

\section{The ethics of reciprocity: a dialogue with Martin Buber}

\author{
Luciana Loyola Madeira Soares* \\ Universidade Veiga de Almeida - UVA, Rio de Janeiro, Rio de Janeiro, Brasil
}

VERISSÍMO, L. J. A ética da reciprocidade: diálogo com Martin Buber. Rio de Janeiro: UapÊ, 2010, 201p.

Para os interessados em Fenomenologia e Existencialismo esta obra é um verdadeiro brinde. Trata-se de um cuidadoso trabalho fruto de desdobramento da tese de doutoramento de Luiz José Verissimo pelo Programa de Pós-graduação em Filosofia da UERJ em 2002, sob o título "A experiência religiosa segundo uma ética da reciprocidade: diálogo com Martin Buber", que contou com a orientação de Olinto Pegoraro.

O leitor é presenteado já no início com o prefácio de Leonardo Boff, que é a reprodução de sua apreciação como membro da banca examinadora da referida tese de doutoramento de Verissimo. A escolha de trazer Boff para prefaciar sublinha a convergência com a noção de ética postulada por ambos os autores.

O livro é composto pela Introdução e três capítulos. Na Introdução já temos um panorama elucidativo da dimensão dialógica que permeará toda a obra: a existência, abordada em sua condição de produção ética pelo viés da filosofia buberiana - a religação do ser humano a outros humanos, assim como caminho para a religação ao sagrado. 0 autor, em máxima fidelidade à obra filosófica de Martin Buber, apresenta-nos sua visão de ética da reciprocidade fundamentada na dialogicidade sob forma de "[...] responsabilidade, cuidado, empatia, decisão, amor, capacidade de formar e de cultivar vínculos, reconhecimento da diferença." (p. 23).

No primeiro capítulo, "Matrizes da experiência religiosa: o 'totalmente outro' e a metafísica", Verissimo se lança a explorar a experiência religiosa apresentando o sagrado como indomesticável que se experimenta nas condições radicais da existência. Para o autor não há um único saber que dê conta de descrever ou explicitar o fenômeno do sagrado, já que este é muito mais da ordem do sentir. Verissimo propõe uma perspectiva relacional para o sagrado; ele afirma que se este é visto como algo superior ou de fora, indica uma noção de desigualdade, anula o humano, portanto, isso sequer pode 
ser chamado de relação. Segundo ele, só a experiência religiosa que celebre uma fé fundada no diálogo, promove uma "[...] ética afirmadora da existência [...]" (p. 35). Tanto o humano quanto o sagrado são legitimados na ética da reciprocidade. Como vemos "Ao visar uma ética que reúne o ser humano ao fundamento sagrado (o ser, Deus), a metafísica tenta resgatar o ser humano do trágico, retomar o fio do sentido, perdido no aniquilamento de um indivíduo reduzido a cinzas." (p. 53).

No segundo capítulo, "Interpretação do sagrado a partir da leitura de Martin Buber", focaliza em especial o sagrado pela perspectiva do encontro - como presença, existência. Para Buber, Deus não é apenas vivido como um "totalmente outro": ele é, sobretudo, "totalmente presença". Assim apresentada, a experiência do sagrado é para o humano uma vivência que o eleva a uma condição mais digna, retirando-o do dualismo em que ele figura como simplesmente matéria vã e perecível em confronto com uma visão de sagrado superior - o "totalmente outro". A visão dialógica distancia-se das dicotomias homem/numinoso, existência/essência, sujeito/objeto, razão/afeto. A vivência, por sua condição tanto cognitiva quanto afetiva, impede que o humano fique puramente no plano irracional ao dedicar-se ao tema do sagrado. "O que ressalta a argumentação dialógica é a articulação radical da palavra com a vivência." (p. 61). No terceiro capítulo, "A condição humana e o sentido ético e psicológico da pessoa.", Verissimo discorre sobre a existência humana e o conceito de pessoa pelos modo de relação Eu e Tu e EuIsso preconizados por Buber. Se no Humanismo o ser humano é alvo e propósito, o Existencialismo o problematiza, abordando o humano enquanto ser relacional, dimensão na qual sua amplitude de possibilidades de experiência se revela. 'O 'Tu' e o 'Isso' são denominações para designar a alteridade e a nossa forma de intencioná-la." ( $p .93$ ), sendo ambos constitutivos da experiência humana. No modo Eu-Isso humanos agem e pensam como coisas (objeto-objeto), fartamente suportados por uma cultura narcisista. Verissimo lembra-nos que isso ocorre quando se fala 'para' ou 'sobre' alguém. O modo de relação Eu e Tu implica no falar 'com' e, portanto, funda a perspectiva dialogal, não comportando dualismos (eu/mundo, dentro/fora, etc.) e sim, a comunicação entre as diferenças. Ao promover uma lógica do 'entre', o Tu acontece diante do Eu sem que seja preciso procurá-lo. Não há como "procurar" alguém no âmbito dialógico, pois o outro é intencionado como presença, e não como objeto. A tentativa de reter uma experiência (seja para quem se projeta na esfera religiosa, seja referida ao entrelaço com o outro) tende a esvaziá-la, enquanto que somente a entrega ao encontro produz a efetiva experiência de alteridade e relação, embora não seja possível obtermos sua posse duradoura. Assim, a relação com o Tu é imediata, integradora e mística, apesar 
de ser fugaz como um lampejo. O autor define mística como ir-aoencontro, e daí parte para afirmar que na perspectiva relacional plenifica-se a pessoa, pois é como se dá a reciprocidade.

Para psicoterapeutas orientados pela Fenomenologia e pelo Existencialismo a presente obra é particularmente uma rica contribuição e um convite à reflexão. Verissimo, psicólogo clínicPUCRJ), ao enfatizar a dialogicidade como fonte de onde brota a ética da reciprocidade, resgata a função da atitude compreensiva do psicoterapeuta, por si só, implicativa, em substituição à explicativa, que coloca os sujeitos em posição assimétrica no cenário terapêutico. Uma vez inspirado por Buber, o psicoterapeuta afasta-se do trabalho que tem o indivíduo "egótico" (autorreferido, autocentrado, narcísico) como objetivo; ao contrário, a meta da psicoterapia passa pela conscientização de que a constituição da pessoa se faz pela relação. O autor alerta-nos para o fato de que o próprio psicoterapeuta e seu cliente surgem de uma "cultura eu-centrada" (p. 186), o que os joga no desafio de dar vez às subjetividades pelo estabelecimento do diálogo genuíno. "A terapia convida o sujeito a experimentar a condição de pessoa." (p. 188). Esta condição, uma vez vivenciada na psicoterapia, fomenta a disponibilidade para a atitude dialógica, para o encontro, para a gênese da ética. Desta maneira, a psicoterapia não se fundamenta apenas no que se passa na sala de atendimento, pois seu alcance abrange e se origina na vida relacional da pessoa. E isso é o que efetivamente pretende o psicoterapeuta que trabalha utilizando a palavra para tecer o delicado tecido do processo terapêutico: dar vez e voz ao cliente através da experiência do cuidado, na reciprocidade, no pleno fluxo dialógico. E, como éticos, não podemos ser na solidão de quatro paredes. A vivência da ética da mútua inclusão no ato terapêutico tanto pode vir a resgatar diálogos abortados, quanto pode abrir as portas para a disposição da pessoa a presentificar-se nas suas relações no mundo.

\section{Referências}

VERISSIIMO, L. J. A ética da reciprocidade: diálogo com Martin Buber. Rio de Janeiro: UapÊ, 2010, 201p.

\section{Endereço para correspondência}

Luciana Loyola Madeira Soares

Rua J osé Higino no 282 ap. 101, Tijuca, RJ

Endereço eletrônico: psi.lucianasoares@gmail.com 
Recebida em: 17/03/2011

Reformulada em: 18/08/2011

Aceita para publicação em: 18/08/2011

Acompanhamento do processo editorial: Deise Mancebo

\section{Notas}

* Professora e Supervisora da graduação em Psicologia (CEUCEL - Centro Universitário Celso Lisboa/RJ); Professora e Supervisora da Pós-graduação em Psicologia Clínica - Gestalt-terapia (CEUCEL); Professora colaboradora do curso de Especialização em Psicologia - Gestalt-terapia (IGT - Instituto de Gestalt-terapia e Terapia Familiar); Membro do LAPSI - UVA (Laboratório de Prática Sociais Integradas - Universidade Veiga de Almeida/RJ); Mestre em Psicanálise, Saúde e Sociedade (UVA); Especialista em Saúde Mental Infanto-juvenil (PUC/Rio Pontifícia Universidade Católica/Rio); Especialista em Psicologia Clínica e em Psicologia Educacional (CRP - Conselho Regional de Psicologia); Psicóloga CRP: 05/6821; Gestalt-terapeuta. 